\title{
LIMITE TERRITORIAL E COISA JULGADA NA AÇÃO CIVIL PÚBLICA: COMENTÁRIOS AO ARTIGO 16 DA LEI 7.347/1985 À LUZ DO JULGAMENTO DO RECURSO EXTRAORDINÁRIO 1.101.937/SP'
}

\author{
TERRITORIAL LIMITATION AND RES IUDICATA IN CIVIL CLASS ACTIONS: \\ REFLECTIONS ON ARTICLE 16 OF LAW 7.347/1985 IN ACCORDANCE WITH \\ THE DECISION RENDERED BY BRAZILIAN SUPREME COURT ON THE \\ EXTRAORDINARY APPEAL 1.101.937/SP
}

Rodrigo Fux Doutorando e Mestre em Direito Processual pela Universidade do Estado do Rio de Janeiro - UERJ. Vice-Diretor de Relações Institucionais do Instituto Brasileiro de Direito Processual IBDP. Membro do Comitê Brasileiro de Arbitragem - CBAr. Advogado. Rio de Janeiro/RJ. E-mail: academia @ fux.com.br.

Pedro Felipe de Oliveira Santos Doutorando em Direito pela Universidade de Oxford. Mestre em Direito pela Universidade de Harvard. Juiz Federal do Tribunal Regional Federal da $1^{\text {a }}$ Região, atualmente convocado como Secretário-Geral da Presidência do Supremo Tribunal Federal. Coordenador Pedagógico da Escola de Magistratura Federal da Primeira Região. Brasília/DF. E-mail: pedro.felipe.santos@gmail.com.

RESUMO: Este artigo trata do recentemente julgamento, pelo Supremo Tribunal Federal, do Recurso Extraordinário 1.101.937/SP, em que se decidiu a respeito da (in)constitucionalidade do artigo 16 da Lei 7.347/1985, o qual previa limitação territorial dos efeitos de sentença proferida em Ação Civil Pública. Para isso, será analisado o

\footnotetext{
${ }^{1}$ Artigo recebido em 05/05/2021 e aprovado em 17/06/2021.
} 
posicionamento histórico da doutrina e da jurisprudência sobre tema, bem como institutos fundamentais do Direito Processual Civil.

PALAVRAS-CHAVE: Coisa Julgada. Eficácia Territorial. Competência Territorial. Ação Civil Pública. Análise Econômica do Direito.

ABSTRACT: This article discusses a recent decision rendered by Brazilian Supreme Court on the Extraordinary Appeal 1.101.937/SP, in which the Court ruled on the (in)constitutionality of article 16 of Law 7.347/1985. The aforementioned statute provided for a territorial limitation of the effects of decisions rendered in Civil Class Actions. In order to achieve the aimed objective, this article will review legal experts and scholars' opinions on the matter, case law and fundamental institutes of Civil Procedural Law.

KEYWORDS: Res Judicata. Territorial Limitations. Territorial Jurisdiction. Class Action. Law and Economics.

\section{Introdução}

Recentemente, o Supremo Tribunal Federal (STF), com o julgamento do Recurso Extraordinário 1.101.937/SP, pôs uma pá de cal na discussão que perdurava desde que a Lei 9.494/1997² alterou o artigo 16 da Lei 7.347/1985 (“Lei da Ação Civil Pública”), trazendo dispositivo que tinha a intenção declarada de restringir a eficácia de sentenças proferidas em ações civis públicas.

O aludido dispositivo dispunha que "a sentença civil fará coisa julgada erga omnes, nos limites da competência territorial do órgão prolator, exceto se o pedido for julgado improcedente por insuficiência de provas, hipótese em que qualquer legitimado poderá intentar outra ação com idêntico fundamento, valendo-se de nova prova".

Conforme se depreende, buscava-se restringir os efeitos de eventual sentença de procedência proferida em ação civil pública ao âmbito da competência territorial do órgão

\footnotetext{
${ }^{2}$ A Lei 9.494/1997 teve origem na conversão da Medida Provisória 1.570-5/1997.
} 
prolator. Exatamente por esse escopo, desde sua origem, a alteração foi amplamente criticada pela doutrina e pouco seguida pela jurisprudência ${ }^{3}$.

Em 26 de março de 2021, o Supremo Tribunal Federal iniciou o julgamento do Recurso Extraordinário 1.101.937/SP e concluiu, em 07 de abril de 2021, "pela inconstitucionalidade do artigo 16 da Lei 7.347/1985, com a redação dada pela Lei 9.494/1997"4, posicionamento em linha com o que sustentado em âmbito doutrinário ${ }^{5}$, posto atribuir a máxima efetividade aos direitos protegidos pelo comando judicial decorrente de tutela coletiva.

No presente ensaio, diante da relevância da matéria e do posicionamento da mais alta corte de nosso País, empreenderemos uma análise (a) dos direitos tutelados pelas ações civis públicas; (b) da incompatibilidade desse mecanismo protetivo com a limitação territorial das decisões judiciais proferidas no bojo dessas ações; e (c) do viés pragmático da decisão definitiva proferida em sede de repercussão geral.

\section{Ações Civis Públicas e Direitos Tutelados}

Como pontificado pela saudosa Ada Pellegrini Grinover, a tutela dos interesses difusos, coletivos e individuais homogêneos consiste em um dos mais relevantes avanços do direito processual civil moderno. A amplitude das ações coletivas lato senso possibilita a

\footnotetext{
${ }^{3}$ Veja-se, a esse respeito, GRINOVER, Ada Pellegrini. A ação civil pública refém do autoritarismo. Revista de Processo, volume 96, 1999, versão eletrônica; WATANABE, Kazuo. Do objeto litigioso das ações coletivas: cuidados necessários para a sua correta fixação. MILARÉ, Édis (coordenador). A Ação civil pública após 25 anos. São Paulo: Editora Revista dos Tribunais, 2010, p. 507; e MENDES, Aluisio Gonçalves de Castro. Ação civil pública: desafios e perspectivas após 25 anos. MILARÉ, Édis (coordenador). A Ação civil pública após 25 anos. São Paulo: Editora Revista dos Tribunais, 2010, p. 68-69.

${ }^{4}$ STF, Recurso Extraordinário 1.101.937/SP, Plenário, Relator Ministro Alexandre de Moraes, julgado na sessão virtual de 26/03/2021 a 07/4/2021.

${ }_{5}^{5}$ PINHO, Humberto Dalla Bernardina; PORTO, José Roberto Mello. Manual de tutela coletiva. São Paulo: Saraiva Educação, 2021, p. 521-526.
} 
defesa eficiente de direitos e interesses massificados, que, muitas vezes, ficariam sem a devida proteção ${ }^{6-}$, não fosse a previsão de mecanismos específicos. ${ }^{7}$

Sobre o tema, nunca é demais rememorar que, no cenário de fuga do formalismo pernicioso, de imperiosa necessidade de entrega efetiva da prestação jurisdicional e de combate à rigidez do processo tradicional, foi erigido o renomado "Movimento de Acesso à Justiça", por meio do qual os juristas Mauro Cappelletti e Bryant Garth desenvolveram o cognominado "Projeto de Florença". O sempre lembrado estudo paradigmático tinha como objetivo justamente realizar uma profunda investigação sobre os problemas em torno da prestação jurisdicional em todo o mundo e suas possíveis soluções ${ }^{8}$.

Como cediço, o Movimento dividiu-se em três etapas - as chamadas ondas renovatórias do acesso à justiça. A primeira tinha o propósito de oferecer soluções a problemas em torno da assistência judiciária, cuidando dos obstáculos econômicos constantemente enfrentados pelas partes para obter a tutela jurisdicional. Debateu-se sobre os custos do litígio e a possibilidade de assistência jurídica pelo Estado.

A segunda, atinente à tutela dos direitos coletivos, inspirou a criação de importantes institutos no Brasil, como a ação popular (Lei 4.717/1965), a ação civil pública (Lei 7.347/1985) e o mandado de segurança coletivo (artigo 5º LXX, da Constituição Federal e artigo 21 e seguintes da Lei 12.016/2009). ${ }^{9}$

\footnotetext{
${ }^{6}$ Pode-se exemplificar como naquelas situações nas quais o "patrimônio" de cada pessoa apenas é atingido em medida muito pequena, que sequer justificaria a propositura de ação judicial, ou mesmo pessoas incapazes de tutelar adequadamente seus direitos por razões de cunho financeiro ou social. Em tais casos, impõe-se a previsão de mecanismos de tutela coletiva. A esse respeito, José Carlos Barbosa Moreira já assentava que "por vezes, [...] o vulto do prejuízo individual não se torna bastante para justificar a ida a Juízo de cada um dos prejudicados isoladamente". MOREIRA, José Carlos Barbosa. Ações coletivas na Constituição Federal de 1988. MILARÉ, Édis (coordenador). A Ação civil pública após 25 anos. São Paulo: Editora Revista dos Tribunais, 2010, p. 364.

7 "A tutela jurisdicional dos interesses difusos, coletivos e individuais homogêneos representa, neste final de milênio, uma das conquistas mais expressivas do Direito brasileiro. Colocados a meio caminho entre os interesses públicos e privados, próprios de uma sociedade de massa e resultado de conflitos de massa, carregados de relevância política e capazes de transformar conceitos jurídicos estratificados, os interesses transindividuais têm uma clara dimensão social e configuram nova categoria política e jurídica". GRINOVER, Ada Pellegrini. A ação civil pública refém do autoritarismo. Revista de Processo, volume 96, 1999, versão eletrônica, item 1.

${ }^{8}$ Sobre o acesso à justiça e as ondas renovatórias, por todos, cf. os próprios idealizadores do movimento: CAPPELLETTI, Mauro; GARTH, Bryant. Acesso à justiça. Trad. Ellen Gracie Northfleet. Porto Alegre: Sergio Antonio Fabris Editor, 2002.

${ }^{9}$ Transcrevemos, a seguir, exposição de Aluisio Mendes a respeito da interseção entre ação civil pública e o Acesso à Justiça: "Os danos resultantes das lesões supramencionadas são, frequentemente, se considerados separadamente, em termos econômicos, de pequena monta, fazendo com que, na relação custo-benefício, o ajuizamento de ações individuais seja desestimulante e, na prática, quase que inexistente, demonstrando, assim, a fragilidade e as deficiências em relação ao acesso à Justiça. A eventual falta ou deficiência dos instrumentos
} 
Revista Eletrônica de Direito Processual - REDP.

Rio de Janeiro. Ano 15. Volume 22. Número 3. Setembro a Dezembro de 2021

Periódico Quadrimestral da Pós-Graduação Stricto Sensu em Direito Processual da UERJ

Patrono: José Carlos Barbosa Moreira (in mem.). ISSN 1982-7636. pp. 930-957

www.redp.uerj.br

A terceira onda renovatória, por fim, buscava avançar mais profundamente nos desafios anteriores, empenhando-se para desenvolver uma verdadeira reorganização institucional do Poder Judiciário, incentivando novas formas de acesso à justiça ${ }^{10}$.

Segundo Teori Zavascki, “[f]oi o legislador brasileiro, na verdade, que protagonizou, de modo muito mais profundo e mais rico do que nos demais países de civil law, a 'revolução', mencionada por Cappelletti e Garth, em prol da criação de instrumentos de tutela coletiva" ${ }^{11}$. Não é para menos, pois a Lei 4.717/1965 e a Lei 7.347/1985 são anteriores à Constituição de $1988^{12}$, em que definitivamente consagrada a tutela de direitos e interesses coletivos. ${ }^{13}$

processuais adequados para os chamados danos de 'bagatela', que, considerados globalmente, possuem geralmente enorme relevância social e econômica, estimula a repetição e perpetuação de práticas ilegais e lesivas. Por conseguinte, tendem a se beneficiar, em vez de serem devidamente sancionados, os fabricantes de produtos defeituosos de reduzido valor, os entes públicos que cobram tributos indevidos ou não concedem os direitos funcionais cabíveis e os fornecedores que realizam negócios abusivamente, apenas para citar alguns exemplos. De pouca ou nenhuma valia passam a ser as normas de direito material, que estabelecem direitos para os lesados, se a referida proteção não encontra, também, amparo efetivo nos meios processuais disponíveis". MENDES, Aluisio Gonçalves de Castro. Ação civil pública: desafios e perspectivas após 25 anos. MILARÉ, Édis (coordenador). A Ação civil pública após 25 anos. São Paulo: Editora Revista dos Tribunais, 2010, p. 63-64. Cândido Rangel Dinamarco também tece interessantes comentários. Ver, a esse respeito, DINAMARCO, Cândido Rangel. Relativizar a coisa julgada. Revista da Procuradoria Geral do Estado de São Paulo, 55/56, janeiro/dezembro de 2001, versão eletrônica, item 1.9.

${ }^{10}$ Sobre os reflexos do movimento de acesso à justiça no Brasil ver CARNEIRO, Paulo Cezar Pinheiro. Acesso à justiça: juizados especiais cíveis e ação civil pública - uma nova sistematização da teoria geral do processo. Rio de Janeiro: Forense, 1999; PINHO, Humberto Dalla Bernardina de. A contribuição de Paulo Cezar Pinheiro Carneiro para a densificação do Princípio do Acesso à Justiça. MENDES, Aluisio Gonçalves de Castro; DINAMARCO, Cândido Rangel; PINHO, Humberto Dalla Bernardina de; FUX, Luiz (coordenadores). Estudos de Direito Processual em Homenagem a Paulo Cezar Pinheiro Carneiro. Rio de Janeiro: Editora GZ, 2019, p. 37-54; FUX, Rodrigo. Acesso à Justiça e suas novas facetas. MENDES, Aluisio Gonçalves de Castro; DINAMARCO, Cândido Rangel; PINHO, Humberto Dalla Bernardina de; FUX, Luiz (coordenadores). Estudos de Direito Processual em Homenagem a Paulo Cezar Pinheiro Carneiro. Rio de Janeiro: Editora GZ, 2019, p. 957-974.

${ }^{11}$ ZAVASCKI, Teori Albino. Processo coletivo: tutela de direitos coletivos e tutela coletiva de direitos, $7^{\mathrm{a}}$ edição. São Paulo: Editora Revista dos Tribunais, 2017, p. 35.

${ }^{12}$ Basta notar a tutela ao meio ambiente sadio (artigo 225), à manutenção do patrimônio cultural (artigo 216), à preservação da probidade administrativa ( $\operatorname{artigo} 37, \S 4^{\circ}$ ), à proteção do consumidor (artigo $5^{\circ}$, inciso XXXII). Também foram incorporados ao texto constitucional o mandado de segurança coletivo (artigo $5^{\circ}$, inciso LXX), a ação popular (artigo $5^{\circ}$, inciso LXXIII).

${ }^{13}$ Ainda sobre a expansão da tutela dos interesses coletivos (em sentido lato), veja-se a exposição de Teoria Zavascki: "Contemporaneamente à introdução dos mecanismos destinados a tutelar direitos transindividuais, foram também criados instrumentos para a tutela coletiva de direitos individuais. No sistema consagrado no Código de Processo Civil de 1973, era admitida, como o é também no Código atual, a defesa conjunta de direitos individuais afins ou comuns de vários titulares, mas desde que ocorresse por regime de litisconsórcio ativo facultativo (CPC/1973, art. 46; CPC/2015, art. 113), ou seja, com a presença dos próprios litisconsortes no polo ativo da relação processual. A Constituição de 1988 expandiu notavelmente uma forma alternativa de tutela coletiva de tais direitos, e o fez adotando a técnica da substituição processual. Com esse desiderato, outorgou legitimação a certas instituições e entidades para, em nome próprio, defender em juízo direitos subjetivos de outrem. Foi o que ocorreu com as entidades associativas (art. $5^{\circ}, \mathrm{XXI}$ ) e sindicais (art. $8^{\circ}$, III), às quais foi conferida legitimação para defender em juízo os direitos dos seus associados e filiados. Da mesma 


\subsection{A Clássica Divisão entre Interesses Difusos, Coletivos e Individuais Homogêneos}

Tradicionalmente, os interesses coletivos (em sentido amplo) são divididos em (a) difusos, (b) coletivos e (c) individuais homogêneos; cujas distinções são de fundamental importância ${ }^{14}$. Ainda no tocante à definição, José Carlos Barbosa Moreira pontuava que há duas espécies de interesses tutelados: aqueles essencialmente coletivos e outros que o são apenas acidentalmente. ${ }^{15}$

Os interesses difusos são aqueles que possuem indeterminação de titulares e indivisibilidade de objeto. Não é possível, em outros termos, definir exatamente a quem pertencem e em que medida, mas evidentemente se pode indicar que são da coletividade. É o caso, por exemplo, do meio ambiente e de alguns aspectos da relação consumerista (como a nocividade de produtos disponibilizados ao mercado). ${ }^{16-17}$

forma, aos partidos políticos com representação no Congresso Nacional, às organizações sindicais, às entidades de classe e às associações atribuiu-se legitimação para impetrar mandado de segurança coletivo 'em defesa dos interesses de seus membros ou associados' (art. $5^{\circ}$, LXX, b)". ZAVASCKI, Teori Albino. Processo coletivo: tutela de direitos coletivos e tutela coletiva de direitos, $7^{\mathrm{a}}$ edição. São Paulo: Editora Revista dos Tribunais, 2017, p. 36.

${ }^{14}$ WATANABE, Kazuo. Do objeto litigioso das ações coletivas: cuidados necessários para a sua correta fixação. MILARÉ, Édis (coordenador). A Ação civil pública após 25 anos. São Paulo: Editora Revista dos Tribunais, 2010, p. 502.

15 “A distinção acima esboçada não tem simples alcance conceptual, mas apresenta grande relevância prática, notadamente no que concerne a determinadas características de processos acaso instaurados com a finalidade de satisfazer os interesses de que cuida. Tratando-se de interesses essencialmente coletivos, em relação aos quais só é concebível um resultado uniforme para todos os interessados, fica o processo necessariamente sujeito a uma disciplina caracterizada pela unitariedade, com todas as consequências de rigor - por exemplo, quanto ao regime do litisconsórcio, na hipótese de ser proposta a ação por dois ou mais interessados. Já no caso de interesses acidentalmente coletivos, uma vez que em princípio se tem de admitir a possibilidade de resultados desiguais para os diversos participantes, a disciplina unitária não deriva em absoluto de uma necessidade intrínseca. Pode acontecer que o ordenamento jurídico, por motivos de conveniência, estenda a essa categoria, em maior ou menor medida, a aplicação de técnicas da unitariedade; esse, porém, é um dado contingente, que não elimina a diferença, radicada na própria natureza das coisas". MOREIRA, José Carlos Barbosa. Tutela jurisdicional dos interesses coletivos ou difusos. Temas de direito processual, $3^{\text {a }}$ série. São Paulo: Saraiva, 1984, p. 196-197.

${ }^{16}$ MOREIRA, José Carlos Barbosa. A ação popular do direito brasileiro como instrumento de tutela jurisdicional dos chamados "interesses difusos". Temas de direito processual, $1^{\text {a }}$ série. São Paulo: Saraiva, 1977, p. 110-123; e WATANABE, Kazuo. Do objeto litigioso das ações coletivas: cuidados necessários para a sua correta fixação. MILARÉ, Édis (coordenador). A Ação civil pública após 25 anos. São Paulo: Editora Revista dos Tribunais, 2010, p. 502.

${ }^{17}$ Artigo 81, parágrafo único, inciso I, do Código de Defesa do Consumidor: “A defesa coletiva será exercida quando se tratar de [...] interesses ou direitos difusos, assim entendidos, para efeitos deste código, os transindividuais, de natureza indivisível, de que sejam titulares pessoas indeterminadas e ligadas por circunstâncias de fato". 
No caso dos danos ambientais, apesar de não haver dúvida de que "todos têm direito ao meio ambiente ecologicamente equilibrado" 18 , não é possível declinar a exata medida do direito de cada pessoa quando determinado poluidor causa dano ambiental. Nesse caso, não será possível fornecer soluções diferentes à coletividade atingida: ou bem se tutela o direito, ou não.

Aqui, a redação do artigo 16 da Lei da Ação Civil Pública era especialmente grave, uma vez que imporia limitações completamente impossíveis, unicamente em razão da competência territorial. Se determinada empresa causou dano ambiental, não se pode dizer que, em outro Estado da Federação, a sentença contra si prolatada não produziria qualquer efeito.

Por sua vez, os interesses coletivos também cumprem importante função. Podem ser definidos como os direitos transindividuais titularizados por um grupo predeterminado, sobretudo em razão de uma relação base pré-existente ${ }^{19}$. Kazuo Watanabe menciona o exemplo interessante do direito tributário, em que, além de a relação jurídica base ser préexistente (relação tributária), a coletividade também é individualizável (contribuintes) ${ }^{20}$.

Nas palavras de José Carlos Barbosa Moreira, “o interesse para o qual se reclama tutela pode ser comum a um grupo mais ou menos vasto de pessoas, em razão do vínculo jurídico que as une a todas entre si, sem, no entanto, situar-se no próprio conteúdo da relação plurissubjetiva" ${ }^{21}$.

Por fim, os interesses individuais homogêneos são aqueles que decorrem de uma origem comum. Apesar de pertencerem a pessoas, decorrem todos de um mesmo fato - ou de um somatório de fatos - e, com isso, podem ser tratados conjuntamente. ${ }^{22}$ Em algumas circunstâncias, o tratamento unitário terá limitações, de forma que a liquidação da extensão

\footnotetext{
${ }^{18}$ Artigo 225 da Constituição da República.

${ }^{19}$ Nesse sentido, veja-se o artigo 81, parágrafo único, inciso II, do Código de Defesa do Consumidor: “A defesa coletiva será exercida quando se tratar de (...) interesses ou direitos coletivos, assim entendidos, para efeitos deste código, os transindividuais, de natureza indivisível de que seja titular grupo, categoria ou classe de pessoas ligadas entre si ou com a parte contrária por uma relação jurídica base”.

${ }^{20}$ WATANABE, Kazuo. Do objeto litigioso das ações coletivas: cuidados necessários para a sua correta fixação. MILARÉ, Édis (coordenador). A Ação civil pública após 25 anos. São Paulo: Editora Revista dos Tribunais, 2010, p. 504.

${ }^{21}$ MOREIRA, José Carlos Barbosa. A ação popular do direito brasileiro como instrumento de tutela jurisdicional dos chamados "interesses difusos". Temas de direito processual, $1^{\text {a }}$ série. São Paulo: Saraiva, 1977.

${ }^{22}$ Artigo 81, parágrafo único, inciso III, do Código de Defesa do Consumidor: “A defesa coletiva será exercida quando se tratar de (...) interesses ou direitos individuais homogêneos, assim entendidos os decorrentes de origem comum".
} 
do dano sofrido terá de ser feita individualmente, levando-se em consideração as peculiaridades de cada caso. ${ }^{23}$

Os requisitos para configuração de direito individual homogêneo são a origem comum e a homogeneidade. Quanto ao primeiro, pode-se exemplificar com a situação em que um mesmo evento causa danos individuais a uma pluralidade de pessoas, como ocorreria em dano ambiental que afete comunidade de pescadores que depende da vida marinha do local acometido. Já a homogeneidade pode ser maior ou menor, a depender da situação, e, em algumas hipóteses, é possível que se tenha de aferir a prevalência do direito coletivo sobre o individual ${ }^{24}$.

Nos últimos dois casos, genericamente referidos como interesses coletivos, a limitação inconstitucional imposta pelo artigo 16 da Lei 7.347/1985, além de inusitada, ainda violaria frontalmente o princípio basilar da igualdade, uma vez que acabaria por tratar pessoas integrantes do mesmo grupo de modo distinta.

\subsection{Novas Perspectivas sobre o Objeto da Ação Civil Pública}

Edilson Vitorelli, em densa tese sobre processo coletivo, afirma que "conquanto essa construção tenha profundo valor histórico, foi possível demonstrar seu caráter insatisfatório, tanto do ponto de vista teórico, quanto pragmaticamente", pois "a classificação do CDC bloqueou as possibilidades de avanço na definição da titularidade dos direitos coletivos, sobretudo os transindividuais" 25 .

\footnotetext{
${ }^{23}$ Essa é exatamente a previsão do artigo 97 do Código de Defesa do Consumidor: "A liquidação e a execução de sentença poderão ser promovidas pela vítima e seus sucessores, assim como pelos legitimados de que trata o art. 82".

${ }^{24}$ Apesar de não ser o objeto principal deste texto, a homogeneidade, enquanto requisito dos interesses individuais homogêneos, não exige que as situações sejam idênticas. É da própria natureza de tais direitos que variem. No entanto, dependendo do grau de homogeneidade (ou de heterogeneidade), possivelmente deverá ser aplicado o conceito de "prevalência da dimensão coletiva sobre a individual" do direito estado-unidense, notadamente para que se possam aferir a possibilidade de tutela coletiva. Ver, a esse respeito, WATANABE, Kazuo. Do objeto litigioso das ações coletivas: cuidados necessários para a sua correta fixação. MILARÉ, Édis (coordenador). A Ação civil pública após 25 anos. São Paulo: Editora Revista dos Tribunais, 2010, p. 506.

${ }^{25}$ VITORELLI, Edilson. O devido processo legal coletivo: dos direitos aos litígios coletivos. São Paulo: Editora Revista dos Tribunais, 2016, p. 443.
} 
Em substituição à divisão expressamente prevista no Código de Defesa do Consumidor, o autor propõe uma tripartição: (a) litígios transindividuais de difusão global ${ }^{26}$; (b) litígios transindividuais de difusão $l_{\text {ocal }}^{27}$; e (c) litígios transindividuais de difusão irradiada $^{28}$. Como se vê, retira-se o foco do direito tutelado para direcioná-lo à espécie de litígio que surgirá, podendo a conflituosidade ser maior ou menor, a depender do tipo.

Em que pese a importância da proposta da tese e todo arcabouço ali desenvolvido, não se pode deixar de jogar luzes no fato de que: (a) que a tripartição de acordo com o direito tutelado encontra previsão expressa no Código de Defesa do Consumidor, não podendo ser simplesmente ignorada pela doutrina; e (b) o processo deve ter, como objetivo, a tutela de direitos, e não necessariamente a divisão em espécies de litígios.

No que diz respeito ao tema que interessa neste breve ensaio, deve-se destacar que o artigo 16 de Lei 7.347/1985 teria, como consequência, impedir a tutela de direitos nos litígios globais e de difusão irradiada. Em tais casos, é necessário que o comando judicial possa ser aplicado a toda coletividade envolvida, que naturalmente ultrapassará a circunscrição territorial de competência de um juiz ou tribunal específicos.

\section{Incompatibilidade do Artigo 16 da Lei $7.347 / 1985$ com o Ordenamento Nacional}

\subsection{Nítida Confusão entre Efeitos da Sentença, Coisa Julgada e Competência Territorial}

A Medida Provisória 1.570-5/1997 trouxe a alteração do artigo 16 da Lei 7.347/1985, passando a prever limitação territorial da coisa julgada proveniente de ação civil pública. Tal

\footnotetext{
26 “[N]os litígios transindividuais de difusão global, o grau de conflituosidade da sociedade titular do direito é muito baixo, pois os indivíduos que a compõem são atingidos pela lesão de modo uniforme e pouco perceptível individualmente, de modo que praticamente não há interesse pessoal no conflito”. Ibidem, p. 80.

27 "A segunda categoria de litígios a ser analisada, e que demanda um conceito diferente de titularidade dos direitos transindividuais, é a das lesões que atingem, de modo específico e grave, comunidades, no sentido que essa expressão tem para Ferdinand Tönnies, ou seja, grupos de reduzidas dimensões e fortes laços de afinidade social, emocional e territorial, traduzidos em um alto grau de consenso interno". Ibidem, p. 80-81.

28 "A última categoria de direitos transindividuais que se pretende formular é a que se relaciona ao que Rodolfo de Camargo Mancuso denominou megaconflitos. Trata-se daquelas situações em que o litígio decorrente da lesão afeta diretamente os interesses de diversas pessoas ou segmentos sociais, mas essas pessoas não compõem uma comunidade, não têm a mesma perspectiva social e não serão atingidas, da mesma forma e com a mesma intensidade, pelo resultado do litígio". Ibidem, p. 85 .
} 
norma foi, então, convertida, pelo Congresso Nacional na Lei 9.494/1997, de forma que a limitação foi definitivamente incorporada ao Ordenamento Nacional.

O artigo 16 passou a prever que "a sentença civil fará coisa julgada erga omnes, nos limites da competência territorial do órgão prolator, exceto se o pedido for julgado improcedente por insuficiência de provas, hipótese em que qualquer legitimado poderá intentar outra ação com idêntico fundamento, valendo-se de nova prova”.

Além de ter tido origem em Medida Provisória, que em tese não poderia versar sobre direito processual (à luz do artigo 62, § 1 o, “c”, da Constituição da República) - o que consiste em vício formal ${ }^{29}$-, a referida alteração legislativa também confundiu os conceitos de competência e coisa julgada. ${ }^{30}$

São conhecidas as numerosas controvérsias doutrinárias em torno da coisa julgada, que pode ser vista como qualidade que se atrela (a) à sentença e a seus efeitos, como sustentado por Enrico Tullio Liebman; (b) exclusivamente à sentença e não aos seus efeitos, na visão de José Carlos Barbosa Moreira; ou (c) unicamente ao conteúdo declaratório da sentença, posição sustentado por Ovídio Baptista. ${ }^{31}$

Enrico Tullio Liebman foi fundamental para que a coisa julgada passasse a ser compreendida como uma qualidade do provimento jurisdicional que o torna imutável (um manto de proteção, uma blindagem), e não mais como um efeito da sentença. Significa dizer que a coisa julgada, a partir da teorização de Liebman, passou a ser vista como um atributo externo à sentença, que a ela se atrela em razão de diversas escolhas dos legisladores

\footnotetext{
${ }^{29}$ WATANABE, Kazuo. Do objeto litigioso das ações coletivas: cuidados necessários para a sua correta fixação. MILARÉ, Édis (coordenador). A Ação civil pública após 25 anos. São Paulo: Editora Revista dos Tribunais, 2010, p. 507.

30 "A inovação é manifestamente inconstitucional, afrontando o poder de jurisdição dos juízes, a razoabilidade e o devido processo legal. A jurisdição, como já visto, não se confunde com a competência. Todos os juízes são investidos na jurisdição, estando limitada tão somente a sua competência para conhecer, processar e julgar processos. Por outro lado, a jurisdição é um poder, decorrente diretamente da soberania, razão pela qual guarda aderência sobre o território nacional, ainda quando o órgão seja estadual. As regras de competência sobre o território fixarão, sim, quem deva ser responsável pelo processo, não se prestando, portanto, para tolher a eficácia da decisão, principalmente sob o prisma territorial". MENDES, Aluisio Gonçalves de Castro. Ações coletivas e meios de resolução de conflitos no direito comparado e nacional, $4^{\mathrm{a}}$ edição. São Paulo: Editora Revista dos Tribunais, 2014, p. 278.

${ }^{31}$ DIDIER JR., Fredie; BRAGA, Paula Sarno; OLIVEIRA, Rafael Alexandria de. Curso de direito processual civil, volume II, $10^{\mathrm{a}}$ edição. Salvador: Editora JusPodivm, 2015, p. 515-516.
} 
constitucional e infraconstitucional, mas que isso não poderia ser confundido como um efeito da sentença. ${ }^{32}$

José Carlos Barbosa Moreira, por sua vez, em que pese enxergar a coisa julgada como efeito jurídico que o ordenamento atribui à sentença, divergia de Liebman no que tange aos efeitos da decisão, aos quais a res judicata não é aplicável. ${ }^{33}$ Sua posição era enfática: "se alguma coisa, em tudo isso, escapa ao selo da imutabilidade, são justamente os efeitos da sentença" ${ }^{34}$, posto que a imutabilidade atinge o conteúdo da sentença.

Por fim, segundo Ovídio Baptista, a coisa julgada seria efeito atribuído pelo ordenamento jurídico unicamente ao conteúdo declaratório da sentença, ou seja, à subsunção da norma aos fatos empreendida pelo julgador. O autor, após intenso diálogo com José Carlos Barbosa Moreira, não vislumbrava a possibilidade de a coisa julgada afetar a eficácia condenatória ou constitutiva. ${ }^{35}$

Seja como for, se a coisa julgada, enquanto atributo que se atrela à sentença, não se confunde com sua eficácia, quiçá será a competência do juízo que ditará os limites de sua

\footnotetext{
32 "Liebman então procurou diferenciar efeito da sentença da autoridade de coisa julgada (auctoritas rei iudicatae): para ele, haveria um erro lógico em considerar a coisa julgada como um efeito da sentença porque os efeitos seriam elementos decorrentes da decisão, ou seja, algo que a sentença gera ou produz porque oriundo de seu comando; já a coisa julgada seria completamente diferente, um predicado que se apõe ou se agrega à decisão após o esgotamento das instâncias recursais. A coisa julgada seria, então, uma qualidade, um atributo, um plus que adere à sentença e assim não poderia ser considerada um efeito da decisão porque não decorre da sentença ou tampouco das normas do direito objetivo por ela aplicadas. Ao contrário, o que torna a sentença imutável e indiscutível é uma norma externa à própria decisão e que não se encontra entre as normas de direito material ou processual aplicáveis ou efetivamente aplicadas para a resolução do conflito de interesses". CABRAL, Antonio do Passo. Alguns mitos do processo (II): Liebman e a coisa julgada. DIDIER JR., Fredie; CABRAL, Antonio do Passo (coordenadores). Coisa julgada e outras estabilidades processuais. Salvador: Editora JusPodivm, 2018, p. 465-466.

33 "Quanto à doutrina liebmaniana, em alguns pontos, sem sombra de dúvida, trouxe à teoria da coisa julgada contribuição que se pode ter por definitivamente adquirida. Assim a demonstração, ao nosso ver irrefutável, de que a 'auctoritas rei iudicatae' se distingue quer do impropriamente chamado 'efeito declaratório', quer, 'in genere', da eficácia da decisão - que, aliás, duvidaríamos em identificar, à maneira de Carnelutti, com a "imperatividade", expressão comprometida com a habitual tendência a enxergar na sentença uma ordem ou comando. A eficácia, entendida simplesmente como aptidão para produzir efeitos (variáveis, é claro, segundo a natureza da decisão), é atributo autônomo, do ponto-de-vista conceptual, em relação à coisa julgada, como atestam os casos em que, inexistente esta, nem por isso se dirá que a sentença seja desprovida de efeitos - sem que, por outro lado, se negue à lei possibilidade de marcar para a produção deles, em caráter absoluto ou como regra geral, um têrmo 'a quo', coincidente com o momento de formação da 'res iudicata'. Nesta hipótese, a sentença só produzirá efeitos, aos menos no comum dos casos, quando se houver tornado imutável; mas nem por isso será me- nos nítida a distinção ontológica entre eficácia e imutabilidade". MOREIRA, José Carlos Barbosa. Ainda e sempre a coisa julgada. Doutrinas Essenciais de Processo Civil, volume 6. São Paulo: Editora Revista dos Tribunais, 2012, versão eletrônica.

${ }^{34}$ MOREIRA, José Carlos Barbosa. Ainda e sempre a coisa julgada. Doutrinas Essenciais de Processo Civil, volume 6. São Paulo: Editora Revista dos Tribunais, 2012, versão eletrônica.

${ }^{35}$ SILVA, Ovídio Araujo Baptista da. Conteúdo da sentença e coisa julgada. Doutrinas Essenciais de Processo Civil, volume 6. São Paulo: Editora Revista dos Tribunais, 2011, p. 287-306.
} 
blindagem. A competência, dentro do território nacional, jamais terá o condão de ser ultrapassar a coisa julgada, como uma espécie de "drible” para não ser respeitada. A decisão, quando não mais passível de impugnação por meio de recurso, fica protegida pela res judicata independentemente da competência do magistrado. Por isso, jamais poderia a Lei 7.347/1985 - ou qualquer lei infraconstitucional - ter restringido referida proteção constitucional, sobretudo fazendo pouco caso de distinções tão caras ao direito processual.

Desde a alteração do artigo 16 da Lei 7.347/1985, relevante parte da doutrina ressaltou a inconsistência da limitação territorial da coisa julgada, posto que fatiaria de forma indevida a tutela de direitos coletivos de pessoas em situações semelhantes. ${ }^{36}$ Se a norma fosse aplicada com rigor, a confusão entre jurisdição, competência territorial e coisa julgada teria gerado situações verdadeiramente catastróficas no mundo real em sede de tutela coletiva.

O legislador, ao alterar a Lei 7.347/1985, confundiu o que orienta o comando jurisdicional e a coisa julgada ${ }^{37}$ que será formada. É que o pedido será o verdadeiro limite imposto, mas jamais a competência do juiz, que funciona como repartição funcional da

\footnotetext{
${ }^{36}$ Fredie Didier Jr. e Hermes Zaneti Jr. trazem interessante exemplo histórico: “[a] legislação não faz sentido. Contraria uma histórica decisão do RS que inaugurou o combate ao tabaco em ambientes fechados. Foi uma decisão judicial da Justiça Federal que proibiu o consumo de tabaco nas aeronaves. A decisão é do final da década de 1990. Imagine se a decisão fosse limitada ao território da Justiça Federal da $4^{a}$ Região, cruzada a fronteira no espaço aéreo todos poderiam começar a fumar. Quando a aeronave ingressasse novamente no espaço aéreo vedado, todos teriam de apagar os cigarros". DIDIER JR., Fredie; ZANETI JR., Hermes. Curso de direito processual civil: processo coletivo, 11 $1^{\mathrm{a}}$ edição. Salvador: Ed. JusPodivm, 2017, p. 448.

De forma semelhante, também pode ser apresentado o exemplo de ação civil pública que verse sobre determinada verba recebida por trabalhadores de empresa que tem diversos polos de operação em estados do Brasil. Os empregados, submetidos à mesma condição, devem receber a mesma tutela do Poder Judiciário.

${ }^{37}$ Veja-se a brilhante exposição de José Carlos Barbosa Moreira a respeito do conceito de coisa julgada: "Quanto à doutrina liebmaniana, em alguns pontos, sem sombra de dúvida, trouxe à teoria da coisa julgada contribuição que se pode ter por definitivamente adquirida. Assim a demonstração, ao nosso ver irrefutável, de que a 'auctoritas rei iudicatae' se distingue quer do impropriamente chamado 'efeito declaratório', quer, 'in genere', da eficácia da decisão - que, aliás, duvidaríamos em identificar, à maneira de Carnelutti, com a 'imperatividade', expressão comprometida com a habitual tendência a enxergar na sentença uma ordem ou comando. A eficácia, entendida simplesmente como aptidão para produzir efeitos (variáveis, é claro, segundo a natureza da decisão), é atributo autônomo, do ponto-de-vista conceptual, em relação à coisa julgada, como atestam os casos em que, inexistente esta, nem por isso se dirá que a sentença seja desprovida de efeitos - sem que, por outro lado, se negue à lei possibilidade de marcar para a produção deles, em caráter absoluto ou como regra geral, um têrmo 'a quo', coincidente com o momento de formação da 'res iudicata'. Nesta hipótese, a sentença só produzirá efeitos, aos menos no comum dos casos, quando se houver tornado imutável; mas nem por isso será me- nos nítida a distinção ontológica entre eficácia e imutabilidade.” (MOREIRA, José Carlos Barbosa. Ainda e sempre a coisa julgada. Doutrinas Essenciais de Processo Civil, volume 6. São Paulo: Editora Revista dos Tribunais, 2012, versão eletrônica).
} 
jurisdição. ${ }^{38}$ Qualquer outra solução seria absolutamente incompatível com o ordenamento jurídico, eis que impossível que se diga, e.g., que determinada decisão não é protegida pelos efeitos da coisa julgada em outro Estado da Federação.

O emérito processualista Aluisio Mendes destaca que "o art. 16 da LACP baralha conceitos heterogêneos - como coisa julgada e competência territorial - e induz a interpretação, para os mais apressados, no sentido de que os 'efeitos' ou a 'eficácia' da sentença podem ser limitados territorialmente, quando se sabe, a mais não poder, que coisa julgada-a despeito da atecnia do art. 467 do CPC - não é 'efeito' ou 'eficácia' da sentença, mas qualidade que a ela se agrega de modo a torná-la imutável e indiscutível" 39 .

Portanto, sob o prisma processual, inexiste limite territorial para coisa julgada no espaço físico de um país. Naturalmente, sendo proferida decisão por juiz brasileiro, ela valerá em todo o território nacional, e será protegida pela autoridade da coisa julgada quando cumpridos seus requisitos, situação em que todos os integrantes do grupo atingido serão beneficiados ${ }^{40}$. Até mesmo pela sua gênese constitucional, a legislação infraconstitucional não poderia mudar a realidade, impondo distopia que não existe.

Um exemplo de fácil visualização é aquele mencionado por Fredie Didier Jr. e Hermes Zaneti Jr. $^{41}$ : não é compatível com a sistemática da coisa julgada que, sendo proferida sentença coletiva que proíba que pessoas fumem em aeronaves, tal comanda apenas seja válido no Estado do Rio Grande do Sul. Caso mantida a teratologia do artigo 16 da Lei da Ação Civil Pública, chegar-se-ia ao absurdo de defender que a companhia,

\footnotetext{
38 “Ora, o âmbito da abrangência da coisa julgada é determinado pelo pedido, e não pela competência. Esta nada mais é do que a relação de adequação entre o processo e o juiz, nenhuma influência tendo sobre o objeto do processo. Se o pedido é amplo (de âmbito nacional) não será por intermédio de tentativas de restrições de competência que o mesmo poderá ficar limitado". GRINOVER, Ada Pellegrini. A ação civil pública refém do autoritarismo. Revista de Processo, volume 96, 1999, versão eletrônica, item 5.

${ }^{39}$ MENDES, Aluisio Gonçalves de Castro. Ações coletivas e meios de resolução de conflitos no direito comparado e nacional, $4^{\text {a }}$ edição. São Paulo: Editora Revista dos Tribunais, 2014, p. 279.

40 “'Com efeito, a Lei 9.494/97 confundiu competência com coisa julgada. A imutabilidade erga omnes de uma sentença não tem nada a ver com a competência do juiz que a profere. A competência importa para saber qual órgão da jurisdição vai decidir a ação; mas a imutabilidade do que ele decidiu estende-se a todo o grupo, classe ou categoria de lesados, de acordo com a natureza do interesse defendido, o que muitas vezes significa, necessariamente, ultrapassar os limites territoriais do juízo que proferiu a sentença”. MAZZILLI, Hugo Nigro. A defesa dos interesses difusos em juízo, 30ª edição. São Paulo: Saraiva, 2017, p. 698.

${ }^{41}$ DIDIER JR., Fredie; ZANETI JR., Hermes. Curso de direito processual civil: processo coletivo, $11^{a}$ edição. Salvador: Ed. JusPodivm, 2017, p. 448.
} 
ingressando no espaço aéreo de outro Estado da Federação (como Santa Catarina), poderia permitir o consumo de produtos derivados do tabaco. ${ }^{42}$

Os artigos 502 e 503 do Código de Processo Civil de 2015 não poderiam ser mais claros ao definir coisa julgada como "a autoridade que torna imutável e indiscutível a decisão de mérito não mais sujeita a recurso" e ao dispor que "a decisão que julgar total ou parcialmente o mérito tem força de lei nos limites da questão principal expressamente decidida”. Como se vê, o códice não menciona qualquer limitação territorial decorrente de competência do órgão julgador.

Aliás, o artigo 516 do CPC/2015 ainda possibilita que o cumprimento de sentença seja iniciado em outro juízo, que não o prolator da sentença, deixando evidente que as decisões judiciais produzem efeitos em todo o território nacional. ${ }^{43}$

De forma clara, a competência territorial do órgão jurisdicional não limita os efeitos da coisa julgada.

\subsubsection{Coisa Julgada na Tutela Coletiva}

Não fosse isso suficiente, o artigo $103^{44}$ do Código de Defesa do Consumidor disciplinou extensamente o funcionamento da coisa julgada em ações coletivas. Em tal dispositivo, há soluções muito simples, quais sejam:

\footnotetext{
42 Aluisio Mendes enumera uma série de instigantes exemplos: "a prosperar a tese contrária, um contrato declarado nulo pela Justiça estadual de São Paulo, por exemplo, poderia ser considerado válido no Paraná; a sentença que determina a reintegração de posse de um imóvel que se estende a território de mais uma unidade federativa (art. 107, CPC) não teria eficácia em relação à parte dele; ou uma sentença de divórcio proferida em Brasília poderia não valer para o Judiciário mineira, de modo que ali as partes pudessem ser consideradas ainda casadas, soluções, todas elas, teratológicas”. MENDES, Aluisio Gonçalves de Castro. Ações coletivas e meios de resolução de conflitos no direito comparado e nacional, $4^{\mathrm{a}}$ edição. São Paulo: Editora Revista dos Tribunais, 2014, p. 279.

${ }^{43}$ Artigo 516, parágrafo único, do CPC/2015: "Nas hipóteses dos incisos II e III, o exequente poderá optar pelo juízo do atual domicílio do executado, pelo juízo do local onde se encontrem os bens sujeitos à execução ou pelo juízo do local onde deva ser executada a obrigação de fazer ou de não fazer, casos em que a remessa dos autos do processo será solicitada ao juízo de origem".

44 “Art. 103. Nas ações coletivas de que trata este código, a sentença fará coisa julgada: I - erga omnes, exceto se o pedido for julgado improcedente por insuficiência de provas, hipótese em que qualquer legitimado poderá intentar outra ação, com idêntico fundamento valendo-se de nova prova, na hipótese do inciso I do parágrafo único do art. 81; II - ultra partes, mas limitadamente ao grupo, categoria ou classe, salvo improcedência por insuficiência de provas, nos termos do inciso anterior, quando se tratar da hipótese prevista no inciso II do parágrafo único do art. 81; III - erga omnes, apenas no caso de procedência do pedido, para beneficiar todas as vítimas e seus sucessores, na hipótese do inciso III do parágrafo único do art. $81 . \S 1^{\circ}$ Os efeitos da coisa julgada previstos nos incisos I e II não prejudicarão interesses e direitos individuais dos integrantes da coletividade, do grupo, categoria ou classe. $\S 2^{\circ} \mathrm{Na}$ hipótese prevista no inciso III, em caso de improcedência
} 
(a). Produção de efeitos erga omnes, quando se tratar de direitos difusos, afetando todos que tenham ou não sido partes do processo coletivo, à exceção da situação em que o pedido for julgado improcedente por insuficiência de provas, situação em que qualquer legitimado poderá intentar outra ação, desde que empregue novas provas (inciso I);

(b). Efeitos ultra partes, mas limitado ao grupo, quando se tratar de ação coletiva que verse sobre interesses ou direitos coletivos, ressalvada também a hipótese em que o pedido é julgado improcedente por insuficiência de provas (inciso II); e

(c). Efeitos erga omnes apenas quando o pedido for julgado procedente, mas também limitado ao grupo, categoria ou classe, quando se tratar de ação coletiva que verse sobre direitos individuais homogêneos (inciso III).

Não há dúvida de que, com a edição do Código de Defesa do Consumidor, a coisa julgada em ações coletivas passou a contar com ampla regulação ${ }^{45}$. O artigo 16 da Lei $7.347 / 1985$, desde a sua edição, não contava com qualquer respaldo no diploma normativo ${ }^{46}$,

do pedido, os interessados que não tiverem intervindo no processo como litisconsortes poderão propor ação de indenização a título individual. $\S 3^{\circ}$ Os efeitos da coisa julgada de que cuida o art. 16, combinado com o art. 13 da Lei $n^{\circ} 7.347$, de 24 de julho de 1985, não prejudicarão as ações de indenização por danos pessoalmente sofridos, propostas individualmente ou na forma prevista neste código, mas, se procedente o pedido, beneficiarão as vítimas e seus sucessores, que poderão proceder à liquidação e à execução, nos termos dos arts. 96 a $99 . \S 4^{\circ}$ Aplica-se o disposto no parágrafo anterior à sentença penal condenatória”.

45 Veja-se, a esse respeito, a contundente explicação de José Manoel de Arruda Alvim Netto: “O sistema adotado nas ações coletivas, a respeito da ocorrência de coisa julgada que, no processo tradicional, deve sempre ocorrer, é o da coisa julgada secundum eventum litis. Ou seja, somente se verifica coisa julgada, 'impeditiva' de ações individuais, quando ocorrer resultado favorável para os beneficiários. Esta é a regra do art. 103, I e II, como também o é para o caso do art. 103, inc. III, com a ressalva de que, neste último caso, os que tiverem intervindo no processo, à luz do disposto no art. 94 (art. 103, § 2..$^{\circ}$ ), não poderão propor ações individuais e, nesta hipótese, a eficácia (negativa à pretensão do autor) se estende, também, negativamente àqueles que poderiam se beneficiar, se favorável tivesse sido o resultado. Ou seja, nesta hipótese ocorre coisa julgada". ALVIM NETTO, José Manoel de Arruda. Notas sobre a coisa julgada coletiva. Revista de Processo, volume 88, 1997, versão eletrônica, item 4.1.

46 "Com o advento do Código de Defesa do Consumidor, a matéria passou a ser regulada inteiramente pelo art. 103, na medida em que instituiu sistema consentâneo com a nova divisão tripartite dos interesses coletivos, nada mais podendo ser aproveitado do art. 16 da Lei 7.347/1985, razão pela qual é de ser considerado revogado, com fulcro no art. $2^{\circ}, \S 1^{\circ}$, parte final, da Lei de Introdução às Normas do Direito Brasileiro. Desse modo, houve manifesto equívoco do legislador ao pretender dar nova redação a dispositivo que não se encontrava mais em vigor". MENDES, Aluisio Gonçalves de Castro. Ações coletivas e meios de resolução de conflitos no direito comparado e nacional, $4^{\mathrm{a}}$ edição. São Paulo: Editora Revista dos Tribunais, 2014, p. 278. 
representando apenas um ponto fora da curva do sistema de tutela coletiva, uma vã tentativa do legislador de tolher e limitar direitos.

Hugo Nigro Mazzilli, em obra acerca da defesa dos interesses difusos em juízo, assenta que o Código de Defesa do Consumidor estendeu a competência do juiz prolator da decisão a todo universo de pessoas afetados, dependendo naturalmente de se tratar de dano regional ou nacional. ${ }^{47}$ Com isso, não são aplicáveis os pretensos limites do artigo 16 da Lei da Ação Civil Pública, mas sim aqueles previstos no artigo $93^{48}$ do Código de Defesa do Consumidor.

Segundo a disposição do artigo 93 do Código de Defesa do Consumidor, ressalvada a competência da Justiça Federal - prevista no artigo 109 da Constituição da República -, será competente para julgar a ação coletiva: (a) o órgão judicial do local em que ocorreu o dano, desde que este se limite a uma localidade específica; (b) os órgãos judiciais do foro da Capital do Estado ou do Distrito Federal, para os danos nacionais ou regionais. Evidentemente, portanto, o artigo especifica que as decisões de juízos de capitais terão aplicabilidade regional ou nacional, a depender da situação fática.

Em tal contexto, não cabia à Lei da Ação Civil Pública restringir a eficácia territorial das decisões judiciais, sob pena de se formularem dois sistemas de tutela coletiva completamente antagônicos, o que representaria, a toda evidência, verdadeira violação à isonomia.

\subsection{Histórico de Julgamentos no Superior Tribunal de Justiça}

\footnotetext{
47 “O CDC estende a competência do juiz prolator a todo Estado ou a todo o País, conforme se trate de dano regional ou nacional (art. 93, II). [...] Assim, os limites da competência territorial do órgão prolator de que trata o art. 16 da Lei n. 7.347/85 não são aqueles fixados na regra de organização judiciária quanto à competência do juízo, mas, sim, os que decorrem do art. 93 do CDC em função do alcance do dano que deu causa à demanda". MAZZILLI, Hugo Nigro. A defesa dos interesses difusos em juízo, $20^{a}$ edição. São Paulo: Saraiva, 2007, o. 527-528.

48 “Art. 93. Ressalvada a competência da Justiça Federal, é competente para a causa a justiça local: I - no foro do lugar onde ocorreu ou deva ocorrer o dano, quando de âmbito local; II - no foro da Capital do Estado ou no do Distrito Federal, para os danos de âmbito nacional ou regional, aplicando-se as regras do Código de Processo Civil aos casos de competência concorrente".
} 
Rio de Janeiro. Ano 15. Volume 22. Número 3. Setembro a Dezembro de 2021

Periódico Quadrimestral da Pós-Graduação Stricto Sensu em Direito Processual da UERJ

Patrono: José Carlos Barbosa Moreira (in mem.). ISSN 1982-7636. pp. 930-957 www.redp.uerj.br

Durante algum tempo, a jurisprudência do Superior Tribunal de Justiça oscilou sobre a validade do artigo 16 da Lei 7.347/1985, bem como sobre seu âmbito de aplicação. ${ }^{49}$

Em um primeiro momento, em 2011, a Corte Especial do Superior Tribunal de Justiça já havia decidido que "se o dano é de escala local, regional ou nacional, o juízo competente para proferir sentença, certamente, sob pena de ser inócuo o provimento, lançará mão de comando capaz de recompor ou indenizar os danos local, regional ou nacionalmente, levados em consideração, para tanto, os beneficiários do comando, independentemente de limitação territorial" ${ }^{50}$. Afastava, portanto, a limitação territorial em casos que versassem sobre qualquer espécie de interesse.

Tempos depois, com o julgamento do Recurso Especial 1.114.035/PR, o Superior Tribunal de Justiça reiterou o entendimento de que o artigo 16 da Lei 7.347/1985 não poderia ser aplicado quando tutelados direitos difusos e coletivos em sentido estrito. Entretanto, delimitou a aplicação do dispositivo "naquelas ações civis públicas que envolvam direitos individuais homogêneos, únicos a admitir, pelo caráter divisível, a possibilidade de decisões eventualmente distintas, ainda que não desejáveis, para os diversos titulares dos direitos autônomos, embora heterogêneos" $"$ 1.

Ou seja, a solução oferecida pelo Superior Tribunal de Justiça vinha no sentido de afastar a aplicação do artigo 16 quando diante de direitos coletivos ou difusos, mas aplicálo quando a tutela envolvesse direito individual homogêneo, que comportaria decisões "eventualmente distintas". 52

Em 2016, o resultado do Recurso Especial 1.243.887/PR foi expressamente referendado nos Embargos de Divergência no Recurso Especial 1.134.957/SP, de relatoria da Ministra Laurita Vaz. Nessa oportunidade, o Superior Tribunal de Justiça sepultou de vez qualquer investida em limitações territoriais das decisões decorrentes de ações civis

\footnotetext{
${ }^{49}$ Nesse sentido, podem ser destacados o Recurso Especial 1.304.953/RS, de relatoria da Ministra Nancy Andrighi, e o Agravo Regimental no Recurso Especial 1.353.720/SC, de relatoria do Ministro Herman Benjamin, em que se chegou à conclusão diametralmente oposta àquela do Supremo Tribunal Federal.

${ }^{50}$ STJ, Recurso Especial 1.243.887/PR, Corte Especial, Relator Ministro Luis Felipe Salomão, julgado em 19 de outubro de 2011.

${ }^{51}$ STJ, Recurso Especial 1.114.035/PR, 2 ${ }^{\text {a }}$ Turma, Relator para Acórdão Ministro João Otávio de Noronha, julgado em 7 de outubro de 2014). Posteriormente, a mesma solução foi adotada em STJ, Recurso Especial 1.331.948/SP, $3^{\text {a }}$ Turma, Relator Ministro Ricardo Villas Bôas Cueva, julgado em 14 de junho de 2016.

${ }^{52}$ A solução, como se pode notar, ainda permitia que fossem proferidas decisões contraditórias e que pessoas pertencentes a um mesmo grupo fossem tratadas de forma desigual, o que não se coaduna com a ordem constitucional vigente.
} 
públicas, atribuindo, portanto, maior proteção aos mecanismos de tutela coletiva. ${ }^{53} \mathrm{Na}$ oportunidade, deixou-se claro que "[o] referido ato não se limitou às ações coletivas para a tutela de interesses individuais homogêneos. Ao contrário, o entendimento firmado pela Corte Especial contempla todos os gêneros das ações coletivas"54.

Assim, o Superior Tribunal de Justiça passou a ter posicionamento uniforme no sentido da impossibilidade de limitação territorial da eficácia da sentença proferida em ação civil pública, independentemente da espécie de direito tutelado (i.e., difuso, coletivo ou individual homogêneo).

\subsection{Inconstitucionalidade do Artigo 16 da Lei da Ação Civil Pública: a Decisão do Supremo Tribunal Federal}

Como se viu, a doutrina já defendia enfaticamente a inconstitucionalidade da alteração introduzida pela Lei 9.494/1997, ou seja, que a limitação territorial (da coisa julgada) decorrente da nova redação do artigo 16 da Lei 7.347/1985 era incompatível com o

\footnotetext{
53 "Embargos de divergência. Processual civil. Art. 16 da Lei da Ação Civil Pública. Ação coletiva. Limitação apriorística da eficácia da decisão à competência territorial do órgão judicante. Desconformidade com o entendimento firmado pela corte especial do superior tribunal de justiça em julgamento de recurso repetitivo representativo de controvérsia (REsp n. ${ }^{\circ}$ 1.243.887/PR, Rel. Min. Luis Felipe Salomão). Dissídio jurisprudencial demonstrado. Embargos de divergência acolhidos. 1. No julgamento do recurso especial repetitivo (representativo de controvérsia) n. ${ }^{\circ}$ 1.243.887/PR, Rel. Min. Luis Felipe Salomão, a Corte Especial do Superior Tribunal de Justiça, ao analisar a regra prevista no art. 16 da Lei n. ${ }^{\circ} 7.347 / 85$, primeira parte, consignou ser indevido limitar, aprioristicamente, a eficácia de decisões proferidas em ações civis públicas coletivas ao território da competência do órgão judicante. 2. Embargos de divergência acolhidos para restabelecer o acórdão de fls. 2.418-2.425 (volume 11), no ponto em que afastou a limitação territorial prevista no art. 16 da Lei n. ${ }^{\circ}$ 7.347/85". (STJ, Embargos de Divergência em Recurso Especial 1.134.957/SP, Relatora Ministra Laurita Vaz, Corte Especial, julgado em 24 de outubro de 2016).

${ }^{54}$ STJ, Embargos de Divergência em Recurso Especial 1.134.957/SP, Relatora Ministra Laurita Vaz, Corte Especial, julgado em 24 de outubro de 2016.
} 
Revista Eletrônica de Direito Processual - REDP.

Rio de Janeiro. Ano 15. Volume 22. Número 3. Setembro a Dezembro de 2021

Periódico Quadrimestral da Pós-Graduação Stricto Sensu em Direito Processual da UERJ

Patrono: José Carlos Barbosa Moreira (in mem.). ISSN 1982-7636. pp. 930-957

www.redp.uerj.br

ordenamento constitucional. ${ }^{55-56}$ Isso porque afrontava o poder jurisdicional dos juízes, a razoabilidade, o devido processo legal, e até mesmo a igualdade ${ }^{57}$.

Em sessão virtual realizada de 26/3 a 7/4/2021, o Supremo Tribunal Federal finalmente dirimiu a questão, decidindo pela incompatibilidade do artigo 16 da Lei da Ação Civil Pública com a ordem constitucional ${ }^{58}$.

De antemão, é elucidativo o processo que deu origem ao entendimento, paradigmático do Tema 1.075 da Repercussão Geral. O acórdão impugnado no Recurso Extraordinário 1.101.937/SP é da lavra da Corte Especial do Eg. Superior Tribunal de Justiça, em sede Embargos de Divergência. Por si só, a circunstância ilustra o grau de maturação da discussão.

$\mathrm{Na}$ origem, o Egrégio Tribunal Regional Federal da $3^{\mathrm{a}}$ Região (TRF-3) deu provimento à pretensão do Instituto Brasileiro de Defesa do Consumidor (IDEC) para conferir eficácia nacional à sentença em Ação Civil Pública. A lide dizia respeito à nulidade de cláusulas em instrumento contratual do Sistema de Financiamento Habitacional (SFH). Não há dúvidas, portanto, sobre o alcance nacional do negócio jurídico controvertido.

O julgamento do Recurso Extraordinário 1.101.937/SP culminou na consolidação de Tese com três itens. A um, a declaração de inconstitucionalidade da redação dada pela Lei

\footnotetext{
${ }^{55}$ MENDES, Aluisio Gonçalves de Castro. Ações coletivas e meios de resolução de conflitos no direito comparado e nacional, $4^{a}$ edição. São Paulo: Editora Revista dos Tribunais, 2014, p. 278.

56 "Por certo, essa inadmissível fragmentação vem sendo feita pelos entes legitimados, inclusive pelo mais atuante deles, que é o Ministério Público, em razão da alteração do art. 16 da Lei 7.347/1985, pela qual a eficácia erga omnes da coisa julgada passou a ter ressalva: 'nos limites da competência territorial do órgão prolator'. No entanto, é necessário ter presente que é inconstitucional essa alteração, porque fere o sistema de acesso à justiça por meio de ação coletiva, assegurada pela nova Constituição, e porque introduzida por meio de medida provisória sem que estivessem presentes os requisitos constitucionais para a sua edição". WATANABE, Kazuo. Do objeto litigioso das ações coletivas: cuidados necessários para a sua correta fixação. MILARÉ, Édis (coordenador). A Ação civil pública após 25 anos. São Paulo: Editora Revista dos Tribunais, 2010, p. 507.

${ }^{57}$ Ana Paula de Barcellos aponta com propriedade a função das ações coletivas na proteção do princípio da igualdade sob o prisma constitucional: "Quanto ao princípio da igualdade, a tutela coletiva tem o potencial de promovê-lo melhor já que a prestação de saúde concedida por um magistrado a determinado indivíduo deveria poder ser concedida também a todas as demais pessoas na mesma situação. Se a decisão judicial que concede determinado bem ou serviço não pode ser razoavelmente universalizada, acaba-se por consagrar uma distribuição no mínimo pouco democrática dos bens públicos: todos custeiam - sem que tenham decidido fazêlo - determinadas necessidades de alguns, que tiveram condições de ir ao Judiciário e obtiveram uma decisão favorável". BARCELLOS, Ana Paula de. Direito processual coletivo e o controle de políticas públicas: os desafios da colaboração e da informação. MENDES, Aluisio Gonçalves de Castro; DINAMARCO, Cândido Rangel; PINHO, Humberto Dalla Bernardina de; FUX, Luiz (coordenadores). Estudos de Direito Processual em Homenagem a Paulo Cezar Pinheiro Carneiro. Rio de Janeiro: Editora GZ, 2019, p. 103.

${ }^{58}$ SUPREMO TRIBUNAL FEDERAL (STF). Recurso Extraordinário 1.101.937 RG-Mérito, Relator Ministro Alexandre de Moraes, Tribunal Pleno, ata de julgamento publicada em 14/4/2021.
} 
9.494/1997 ao art. 16 da LACP, com a consequente repristinação da fórmula original, foi acompanhada de duas outras implicações. A dois, a competência funcional do foro para o processamento dessas ações de escopo regional ou nacional, em conformidade com o art. 93 do CDC. A três, o esclarecimento sobre a prevenção no órgão jurisdicional que recebeu a primeira $\mathrm{ACP}^{59}$.

Cumpre perquirir quais foram os fundamentos determinantes que a Corte Constitucional adotou. Ainda que o "placar" tenha sido de 7 a 2 (com duas abstenções justificadas) em favor do voto do Relator, é possível discernir uma multiplicidade de contextos de justificação que concorreram para conclusões similares dos Ministros.

$\mathrm{O}$ voto condutor, da lavra do e. Min. Alexandre de Moraes, superou importante preliminar com reflexos diretos sobre a leitura que o Supremo faz dos tipos de demandas coletivas. Concluiu-se pela não aplicabilidade do Tema 499 da Repercussão Geral à espécie. A partir do cotejo, o colegiado distinguiu entre os efeitos subjetivos da ação coletiva de rito ordinário, clássica relação jurídico-processual de representação (associação-associações) e a tutela em ACP, reafirmando que o microssistema processual coletivo pós-1990 extrapola a individualização dos beneficiários e os interesses restritos.

A tônica que perpassou as manifestações da maioria formada foi esta: o artigo da Lei da Ação Civil Pública precisa ser concretizado à luz do arcabouço do Código de Defesa do Consumidor. Essa complementação se dá quanto à classificação da tutela vindicada (direitos difusos, coletivos e individuais homogêneos, na forma do art. 81 do CDC); quanto à fixação de competência funcional do Juízo, a partir da extensão dos efeitos (art. 93 do CDC); e quanto à eficácia subjetiva da coisa julgada (ultra partes ou erga omnes, segundo o art. 103 do CDC).

Dentre os julgadores que formaram o quórum para a aprovação da Tese, os termos “celeridade", "racionalização", “economia processual", "acesso à Justiça” e "eficiência" parecem ter construído a ponte argumentativa, no cerne da ratio decidendi ${ }^{60}$. O ímpeto de

\footnotetext{
${ }^{59} \mathrm{Na}$ íntegra: “I - É inconstitucional o art. 16 da Lei 7.347/1985, alterada pela Lei 9.494/1997.

II - Em se tratando de ação civil pública de efeitos nacionais ou regionais, a competência deve observar o art. 93, II, da Lei 8.078/1990.

III - Ajuizadas múltiplas ações civis públicas de âmbito nacional ou regional, firma-se a prevenção do juízo que primeiro conheceu de uma delas, para o julgamento de todas as demandas conexas".

60 "Patente, pois, o desrespeito aos princípios da igualdade, eficiência, segurança jurídica e efetiva tutela jurisdicional, como bem destacado pela Procuradoria Geral da República, que destacou: 'Interpretação nesses moldes aponta para a existência de um direito fundamental à tutela jurisdicional coletivo adequada,
} 
dar máximo proveito à decisão conforme a identidade de causa de pedir e pedido, em todo o território, esteve presente, inclusive, no voto do Exmo. Ministro Edson Fachin, computado com ressalvas ao Relator.

$\mathrm{Na}$ prática, a única divergência quanto às premissas foi veiculada pelo Ministro Marco Aurélio de Mello, para quem a eficácia erga omnes do CDC deve ser interpretada em respeito aos limites territoriais da jurisdição. De tal sorte que o Vogal afirma que a restrição espacial dos efeitos prevista na norma é pedagógica, mero esclarecimento de uma leitura que sobrepõe os conceitos de "jurisdição" e "competência".

Felizmente, o saldo do julgado é positivo para uma aplicação cada vez mais propositada dos instrumentos processuais de garantias transindividuais. Com essa tese, após anos de reclamos da comunidade jurídica, o Supremo Tribunal Federal proferiu decisão que valoriza a Carta Magna e protege a tutela coletiva no Brasil, mantendo o protagonismo do país em tal matéria.

$\mathrm{Na}$ próxima seção, a lógica prevalecente no acórdão será desenvolvida sob a perspectiva da Análise Econômica do Direito, especialmente sobre a necessidade de se coibir o ajuizamento pulverizado de Ações Civis Públicas que comportam julgamento unificado.

\section{O julgamento do Supremo Tribunal Federal sob uma perspectiva pragmática: eficiência e futuro da tutela dos direitos transindividuais}

A essa altura, o viés pragmático da decisão já se encontra explícito ${ }^{61}$. Diz-se pragmático, porque rechaça a leitura formalista sobre os limites da autoridade decisória ${ }^{62}$. A proposta de alcance da coisa julgada a partir da abrangência do dano é a marca de um Tribunal consciente acerca dos custos mobilizados por causas repetidas.

\footnotetext{
compreendida essa como a que (i) facilite o amplo acesso à Justiça (art. $5^{\circ}, \mathrm{XXXV}$ ); (ii) favoreça a efetiva e eficaz entrega da prestação jurisdicional (arts. $5^{\circ}$, LXXVIII, 37, caput, 127, caput, e 129, caput e III); (iii) dê tratamento isonômico aos jurisdicionados (art. $5^{\circ}$, caput); e (iv) proteja a vulnerabilidade dos detentores do direito coletivo reivindicado (art. 5, XXXII, XXXV e XXXVI)'”. STF, Recurso Extraordinário 1.101.937/SP, Plenário, Relator Ministro Alexandre de Moraes, julgado na sessão virtual de 26/03/2021 a 07/4/2021.

${ }^{61}$ Vide POSNER, R. Law, pragmatism and democracy. Cambridge: Harvard University Press, 2003.

${ }^{62}$ Cf. POSNER, 2003, p. 84.
} 
Sob o olhar institucional, a função jurisdicional é una e indivisível, de modo que a responsabilidade por medidas que corrijam posturas inadequadas de litigiosidade é exercida transversalmente pelo Poder Judiciário, exigindo visão sistêmica das instâncias superiores.

A unidade na condução da fase cognitiva de Ação Civil Pública com efeito multiplicador até o momento de formação de sentença condenatória consagra uma aproximação aos ideais do "nível ótimo de litigância" e do "desenho ótimo do sistema processual”, ambos os conceitos trabalhados em obra seminal de Steven Shavell ${ }^{63}$.

O "nível ótimo de litigância" ("socially optimal amount of suits") é a unidade analítica que representa o cenário em que a soma dos custos sociais de todas as ações judiciais são os menores possíveis ${ }^{64}$. Entretanto, essa situação pressupõe que os requerentes estão orientados a considerar impactos além de suas despesas individuais com o processo, em uma análise prospectiva complexa, que envolveria os custos para o Estado-juiz e os prejuízos suportados pelos requeridos ${ }^{65}$.

Ante a intangibilidade do resultado ideal, o patamar socialmente aceitável de litigiosidade engloba a maximização de três variáveis: (a) o poder dissuasivo e persuasivo das decisões judiciais em relação às condutas, (b) a justa compensação das vítimas de danos e (c) a fixação de precedentes de alta respeitabilidade ${ }^{66}$. Assim, as demandas de valor social positivo são aquelas que atendem aos objetivos mencionados.

Por outro lado, Shavell (2004, p. 398) atribui função corretiva às políticas públicas, entre elas as políticas judiciárias, para intervir no nível de litigância. Com esse escopo, o ajuizamento de certas ações poderia ser desincentivado ou promovido. A regulamentação das ações coletivas se insere nessa última categoria das demandas moldadas por incentivos normativos positivos.

\footnotetext{
63 SHAVELL, Steven. Foundations of economic analysis of law. London: The Belknap Press of Harvard University Press, 2004.

${ }^{64}$ SHAVELL, 2004, pp. 389-401.

65 Ibid., pp. 389-390.

${ }^{66} \mathrm{O}$ seguinte trecho bem sintetiza: "[o]n the other hand, the private benefits from suit will be what the plaintiff will win from suit, usually money, whereas the social benefits from suit will ordinarily be different: They will always include deterrence benefits and may also include compensation of victims (if insurance is unavailable) and the setting of precedent. Potential plaintiffs will not tend to take all of these social benefits into account" (SHAVELL, 2004, p. 394).
} 
Na Ação Civil Pública, os custos da ação ${ }^{67}$ já são naturalmente compartilhados pela coletividade lesada. A socialização dos custos pode ter bases menores, como os partícipes de uma associação, ou bases amplas, como é o caso de toda a população de um ente federativo cujos interesses são representados pelo parquet. Principalmente nesse quadro em que atores institucionais são os proponentes, justifica-se que os atos processuais instrutórios sejam concentrados em um único Juízo.

Afinal, é despiciendo que a mesma situação fática sofra apuração mais de uma vez, ainda mais sob o risco sistêmico de pronunciamentos judiciais divergentes, suscitando insegurança jurídica.

Em país de dimensões continentais como o Brasil, a dupla (que pode tripla, quádrupla, múltipla) tramitação de ACPs correlatas é fenômeno em que as pessoas políticoadministrativas deixam de auferir os benefícios sociais ocasionados pela segurança jurídica e pela celeridade e perdem com a alocação ineficiente dos advogados públicos e com a produção de provas periciais. Onerosas perícias são comuns para a aferição de danos ambientes ou para o levantamento de valores desviados em atos ímprobos, dois objetivos típicos dessa via.

Como adiantado, o instituto da ação civil pública dialoga ainda com a busca pelo "desenho processual ótimo" ("socially optimal legal system") ${ }^{68}$. O ideal abarcaria as previsões de garantias processuais (e.g. contraditório e ampla defesa) e as normas procedimentais sequenciadas até a adjudicação ${ }^{69}$.

Enquanto o ponto ótimo de litigância almeja o mínimo de onerosidade social $^{70}$, o desenho processual ótimo visa ao máximo de bem-estar social que um dado grau de rigor procedimental é capaz de prover. Trata-se do equilíbrio entre os custos do aumento marginal em acurácia do processo judicial versus o incremento em pacificação social ${ }^{71}$.

\footnotetext{
${ }^{67}$ Tradução livre, próxima à expressão "costs of a suit". Não se pode perder de vista, porém, que o "suit" é a etapa inicial onerosa que serve de pré-requisito para a solução judicial do conflito. Shavell (2004, pág. 389) se vale de um conceito econômico de ação.

68 "General Topics on the Legal Process". SHAVELL, 2004, Chapter 19, pp. 444-470.

${ }^{69}$ Ibid., p. 444.

70 "Basic Theory of Litigation”. SHAVELL, 2004, Chapter 17, pp. 389-419.

${ }^{71}$ No escrito original: "Here I will discuss first the social value of accuracy of the legal process: the increase in social welfare that greater accuracy brings about. The social value of accuracy inheres in its effects on outcomes, and notably in its effects on the behavior of parties who anticipate greater accuracy of the legal process; accuracy is not valued in itself. As will become evident, the social value of accuracy depends in significant ways on context" (SHAVELL, 2004, p. 451).
} 
Os limites fáticos do investimento eficaz nessa complexificação da sistemática processual ficam mais claros quando se têm em mente os elementos considerados para aferição de resultados socialmente desejáveis ${ }^{72}$.

O primeiro desses três elementos é a influência sobre os comportamentos dos jurisdicionados. Shavell (2004, pp. 351-352) explica esse ponto com base na ineficácia dissuasiva da sanção perante ilícitos de responsabilidade civil culposos. $\mathrm{O}$ aparelhamento do Poder Judiciário para revelar e quantificar o dano, a partir de certo ponto, deixa de ser eficaz para convencer os agentes sobre as cautelas necessárias.

O segundo e o terceiro componentes do valor social gerado pela acurácia do processo judicial seguem lógica similar, razão pela qual podem ser comentados a uma só vez. São eles (a) a redução geral dos custos de litigância para as partes e dos custos estatais para a implementação de sanções e (b) menor margem de risco quanto à imprevisibilidade do resultado da ação. Para ambas as expectativas, a acurácia do processo judicial possui influência restrita ${ }^{73}$.

Tanto a adoção de soluções consensuais quanto a análise de custo-benefício da ação não dependem apenas da estrutura de incentivos canalizados pelo procedimento. Pressupõem, na origem, interesses e prospecções subjetivas.

Isso sem mencionar que nem sempre as partes se conduzirão perante a Justiça com a melhor intenção de reconstituir a verdade. Não raro, a percepção individual do sujeito de direito sobre a utilidade do processo é totalmente incongruente com a operação de um desenho processual ótimo.

Transpondo as premissas dessa categoria de AED para a sistemática da ação civil pública, a ubiquidade territorial da decisão prolatada pelo magistrado competente de acordo com o art. 93 do CDC serve à otimização dos esforços e dos recursos destinados ao enquadramento da demanda regional ou nacional. Gera-se o bem-estar social dos beneficiários, sem a repetição de inúmeros ônus.

Importante frisar que a eficácia erga omnes da sentença em ACP não é "carta branca" nem direito absoluto. As diligências necessárias para a adequação da ordem à realidade do titular do direito, inclusive daquele cidadão que se encontra sob jurisdição diversa da

\footnotetext{
${ }^{72}$ SHAVELL, op. cit., p. 451-456.

${ }^{73}$ SHAVELL, op. cit., p. 454.
} 
sentenciante, são deixadas para a fase de liquidação e/ou de execução, o que já ocorreria de todo modo.

\section{Conclusão}

Este breve ensaio analisou a alteração do artigo 16 da Lei da Ação Civil Pública decorrente da Lei 9.494/1997, que, por sua vez, resultou da conversão da Medida Provisória 1.570-5/1997. O dispositivo, com sua nova redação, passou a confundir conceitos de coisa julgada e competência, limitando, de forma indevida, os efeitos de provimentos jurisdicionais em ações coletivas ao âmbito de atuação do órgão.

Como demonstrado, referida alteração contrariou a lógica do ordenamento nacional, notadamente no que diz respeito à estruturação e às finalidades da tutela coletiva. Houve (a) nítida confusão entre coisa julgada, jurisdição e competência territorial do juízo; (b) violação ao funcionamento da coisa julgada no processo coletivo, tal qual regulada no artigo 103 do Código de Defesa Consumidor; e (c) ofensa a numerosos princípios constitucionais, tais como a Igualdade, a Eficiência, a Segurança Jurídica e a Efetiva Tutela Jurisdicional.

Por tais razões, o Supremo Tribunal Federal, ao julgar o Recurso Extraordinário 1.101.937/SP, andou bem ao reputar inconstitucional o artigo 16 da Lei 7.347/1985, na redação estabelecida pela Lei 9.494/1997. Claramente ponderou as consequências dos provimentos jurisdicionais e deu voz aos reclamos da comunidade jurídica, que, desde o final dos anos 1990, já vinha defendendo a impositiva declaração de inconstitucionalidade do dispositivo.

Não se poderia deixar, a essa altura, de rememorar os valiosos ensinamentos da Professora Ada Pellerini Grinover: "[a] notável quantidade de demandas e a adequada resposta jurisdicional iluminaram as novas técnicas processuais e demonstraram o empenho dos legitimados - primeiro, dentre todos, o Ministério Público -, e a ampla gama das ações ajuizadas, o reconhecimento do corpo social" e "[n]esse quadro se inseriu significativamente o Poder Judiciário brasileiro, consciente de seu novo papel e de sua renovada importância, 
sabendo marcar, com seus julgamentos, uma posição de vanguarda, que aponta auspiciosamente para os futuros desafios"74.

Fazemos votos para que, na esteira da recente decisão do Supremo Tribunal Federal, o Poder Judiciário continue a ser protagonista de proteção da tutela coletiva, protegendo seus instrumentos e efetivamente garantindo o Acesso à Justiça.

\section{REFERÊNCIAS}

ALVIM NETTO, José Manoel de Arruda. Notas sobre a coisa julgada coletiva. Revista de Processo, volume 88, 1997, versão eletrônica.

BARCELLOS, Ana Paula de. Direito processual coletivo e o controle de políticas públicas: os desafios da colaboração e da informação. MENDES, Aluisio Gonçalves de Castro; DINAMARCO, Cândido Rangel; PINHO, Humberto Dalla Bernardina de; FUX, Luiz (coordenadores). Estudos de Direito Processual em Homenagem a Paulo Cezar Pinheiro Carneiro. Rio de Janeiro: Editora GZ, 2019.

CABRAL, Antonio do Passo. Alguns mitos do processo (II): Liebman e a coisa julgada. DIDIER JR., Fredie; CABRAL, Antonio do Passo (coordenadores). Coisa julgada e outras estabilidades processuais. Salvador: Editora JusPodivm, 2018.

CAPPELLETTI, Mauro; GARTH, Bryant. Acesso à justiça. Trad. Ellen Gracie Northfleet. Porto Alegre: Sergio Antonio Fabris Editor, 2002.

CARNEIRO, Paulo Cezar Pinheiro. Acesso à justiça: juizados especiais cíveis e ação civil pública - uma nova sistematização da teoria geral do processo. Rio de Janeiro: Forense, 1999.

DINAMARCO, Cândido Rangel. Relativizar a coisa julgada. Revista da Procuradoria Geral do Estado de São Paulo, 55/56, janeiro/dezembro de 2001, versão eletrônica. DIDIER JR., Fredie; BRAGA, Paula Sarno; OLIVEIRA, Rafael Alexandria de. Curso de direito processual civil, volume II, 10ª edição. Salvador: Editora JusPodivm, 2015.

DIDIER JR., Fredie; ZANETI JR., Hermes. Curso de direito processual civil: processo coletivo, 11 $1^{\text {a }}$ edição. Salvador: Ed. JusPodivm, 2017.

\footnotetext{
${ }^{74}$ GRINOVER, Ada Pellegrini. A ação civil pública refém do autoritarismo. Revista de Processo, volume 96, 1999, versão eletrônica, item 7.
} 
FUX, Rodrigo. Acesso à Justiça e suas novas facetas. MENDES, Aluisio Gonçalves de Castro; DINAMARCO, Cândido Rangel; PINHO, Humberto Dalla Bernardina de; FUX, Luiz (coordenadores). Estudos de Direito Processual em Homenagem a Paulo Cezar Pinheiro Carneiro. Rio de Janeiro: Editora GZ, 2019.

GRINOVER, Ada Pellegrini. A ação civil pública refém do autoritarismo. Revista de Processo, volume 96, 1999, versão eletrônica.

MAZZILLI, Hugo Nigro. A defesa dos interesses difusos em juízo, 30 edição. São Paulo: Saraiva, 2017.

MENDES, Aluisio Gonçalves de Castro. Ação civil pública: desafios e perspectivas após 25 anos. MILARÉ, Édis (coordenador). A Ação civil pública após 25 anos. São Paulo: Editora Revista dos Tribunais, 2010.

MENDES, Aluisio Gonçalves de Castro. Ações coletivas e meios de resolução de conflitos no direito comparado e nacional, $4^{\text {a }}$ edição. São Paulo: Editora Revista dos Tribunais, 2014.

MOREIRA, José Carlos Barbosa. A ação popular do direito brasileiro como instrumento de tutela jurisdicional dos chamados "interesses difusos". Temas de direito processual, $1^{\mathrm{a}}$ série. São Paulo: Saraiva, 1977.

MOREIRA, José Carlos Barbosa. Ações coletivas na Constituição Federal de 1988. MILARÉ, Édis (coordenador). A Ação civil pública após 25 anos. São Paulo: Editora Revista dos Tribunais, 2010.

MOREIRA, José Carlos Barbosa. Ainda e sempre a coisa julgada. Doutrinas Essenciais de Processo Civil, volume 6. São Paulo: Editora Revista dos Tribunais, 2012, versão eletrônica.

MOREIRA, José Carlos Barbosa. Tutela jurisdicional dos interesses coletivos ou difusos. Temas de direito processual, $3^{\mathrm{a}}$ série. São Paulo: Saraiva, 1984.

PINHO, Humberto Dalla Bernardina de. A contribuição de Paulo Cezar Pinheiro Carneiro para a densificação do Princípio do Acesso à Justiça. MENDES, Aluisio Gonçalves de Castro; DINAMARCO, Cândido Rangel; PINHO, Humberto Dalla Bernardina de; FUX, Luiz (coordenadores). Estudos de Direito Processual em Homenagem a Paulo Cezar Pinheiro Carneiro. Rio de Janeiro: Editora GZ, 2019. 
PINHO, Humberto Dalla Bernardina; PORTO, José Roberto Mello. Manual de tutela coletiva. São Paulo: Saraiva Educação, 2021.

POSNER, R. Law, pragmatism and democracy. Cambridge: Harvard University Press, 2003.

SHAVELL, Steven. Foundations of economic analysis of law. London: The Belknap Press of Harvard University Press, 2004.

SILVA, Ovídio Araujo Baptista da. Conteúdo da sentença e coisa julgada. Doutrinas Essenciais de Processo Civil, volume 6. São Paulo: Editora Revista dos Tribunais, 2011, p. 287-306.

SUPREMO TRIBUNAL FEDERAL (STF). Recurso Extraordinário 1.101.937 RG-Mérito, Relator Ministro Alexandre de Moraes, Tribunal Pleno, ata de julgamento publicada em $14 / 4 / 2021$.

VITORELLI, Edilson. O devido processo legal coletivo: dos direitos aos litígios coletivos. São Paulo: Editora Revista dos Tribunais, 2016.

WATANABE, Kazuo. Do objeto litigioso das ações coletivas: cuidados necessários para a sua correta fixação. MILARÉ, Édis (coordenador). A Ação civil pública após 25 anos. São Paulo: Editora Revista dos Tribunais, 2010.

ZAVASCKI, Teori Albino. Processo coletivo: tutela de direitos coletivos e tutela coletiva de direitos, $7^{\mathrm{a}}$ edição. São Paulo: Editora Revista dos Tribunais, 2017. 